\title{
Spatialization of Tibraca limbativentris Stål in irrigated rice: a geostatistical approach
}

\section{Espacialização de Tibraca limbativentris Stål em arroz irrigado: uma abordagem geoestatística}

\author{
Mauricio Paulo Batistella Pasini ${ }^{1}$ (1) (https://orcid.org/0000-0002-3538-8397) \\ Eduardo Engel ${ }^{2 *}$ (D) (https://orcid.org/0000-0001-8218-6248) \\ Alessandro Dal'Col Lúcio3 (iD (https://orcid.org/0000-0003-0761-4200) \\ Alberto Cargnelutti Filho3 (D) (https://orcid.org/0000-0002-8608-9960) \\ Ana Lúcia de Paula Ribeiro4 (D) (https://orcid.org/0000-0003-0193-2099) \\ Rafael Pivoto Bortolotto ${ }^{1}$ (D) (https://orcid.org/0000-0003-2102-2471) \\ João Fernando Zamberlan' (D) (https://orcid.org/0000-0003-1707-2580)
}

\begin{abstract}
The objective was to identify the dispersion of Tibraca limbativentris (Hemiptera: Pentatomidae) in different phenological phases of irrigated rice. The research was carried out in an area of 20.12 ha, subdivided in four fields of 0.25 to 14.1 ha with the irrigated rice culture, grown under the technical recommendations of the culture. In each field, a sampling grid of $30 \times 30 \mathrm{~m}$ was generated, with each sampling point corresponding to $1 \cdot \mathrm{m}^{-2}$ (200 plants), sampling was through direct counting. The number of adults of T. limbativentris $\cdot \mathrm{m}^{-2}$ was subjected to descriptive and geostatistical analyzes. Tibraca limbativentris presents border dispersion towards the center of the irrigated rice cultivation area. The highest population densities were estimated in the anthesis and elongation phase.
\end{abstract}

KEYWORDS: interpolators; Poaceae; Pentatomidae; regionalized variables; Oryza spp.
RESUMO: O objetivo foi identificar a dispersão de Tibraca limbativentris (Hemiptera: Pentatomidae) em diferentes fases fenológicas do arroz irrigado. A pesquisa foi realizada em uma área de 20,12 ha, subdividida em quatro lavouras de 0,25 a 14,1 ha com a cultura de arroz irrigado, cultivadas sob as recomendaçóes técnicas da cultura. Em cada lavoura, foi gerado um grid de amostragem de $30 \times 30 \mathrm{~m}$ sendo cada ponto amostral correspondente a $1 \cdot \mathrm{m}^{-2}$ (200 plantas), a amostragem realizada foi através de contagem direta. O número de adultos de T. limbativentris $\mathrm{m}^{-2}$ foi submetido a análises descritivas e geoestatística. Tibraca limbativentris apresenta dispersão das bordaduras para o centro da área de cultivo de arroz irrigado. As maiores densidades populacionais foram estimadas na fase de antese e elongação.

PALAVRAS-CHAVE: interpoladores; Poaceae; Pentatomidae; variáveis regionalizadas; Oryza spp.

\footnotetext{
'Universidade de Cruz Alta - Laboratório de Entomologia - Cruz Alta (RS), Brazil.

${ }^{2}$ Universidade de São Paulo - Departamento de Entomologia e Acarologia - Laboratório de Ecologia e Entomologia Florestal - Escola Superior de Agricultura "Luiz de Queiroz" - Piracicaba (SP), Brazil

${ }^{3}$ Universidade Federal de Santa Maria - Departamento de Fitotecnia - Santa Maria (RS), Brazil

${ }^{4}$ Instituto Federal de Educação Ciência e Tecnologia Farroupilha - Laboratório de Entomologia - São Vicente do Sul (RS), Brazil.

*Corresponding author: agron.engel@gmail.com

Received on: 11/06/2018. Accepted on: 08/02/2020
} 


\section{INTRODUCTION}

The stink bug Tibraca limbativentris (Hemiptera: Pentatomidae) occurs in all rice regions in Latin America, reducing the productive potential of rice culture (RAMPELOTTI et al., 2008; PAZINI et al., 2012). This species occurs throughout the phenology of rice, varying its damage according to the stage of the crop. When it attacks the culm, the symptom called dead heart occurs, reducing the plant stand (SOUZA et al., 2009). In the reproductive stage, generates the panicle formation of white or partial sterility of spikelets, which is the most influential component in reducing the yield of rice grains (OLIVEIRA et al., 2010). As estimated by the same authors, one stink bug per $\mathrm{m}^{2}$ reduces $1.2 \%$ of grain yield. In high infestations, their damage can reach $90 \%$ in reducing grain production (FERREIRA et al., 1997).

During the off-season of irrigated rice, T. limbativentris establishes itself in sites of aggregation and quiescence around the crops and, from sowing, individuals infest the cultivation areas, promoting population growth due to their fertility (FERREIRA et al., 1997). The dispersion of individuals in the cultivation areas is mainly motivated by the food searches, reproduction, places for oviposition and the escape of predators (WALZER et al., 2009).

The detailed knowledge of T. limbativentris dispersion in crops in the irrigated rice crop development stages is important for the establishment of integrated management. Suppressive actions in the populations of this insect pest can be taken from this knowledge, influencing production costs and less environmental contamination, in addition to being a precursor of management techniques with precision agriculture (PASINI et al., 2014).

Population densities of pest insects in crops can be estimated using interpolation procedures, generating spatial distribution maps from sample points (WEBSTER; OLIVER, 2007). Among the interpolation methods, ordinary kriging is considered one of the most precise and accurate, with reliable estimates and with the least errors (COELHO et al., 2009; SOUZA et al., 2010; SILVA et al., 2010; DINARDO-MIRANDA et al., 2011; PASINI et al., 2014, 2015; PAZINI et al., 2015).

According to LEE et al. (2014), studies on the dispersion of insect pests help in understanding the biology of populations and in the development of sampling procedures and strategies for controlling insect pests. Information on the dispersion and spatial distribution of T. limbativentris is available (FERREIRA et al., 1997; PAZINI et al., 2015), however, they lack further details, through a greater number of evaluations in different cultivation areas, in the same agricultural year, with new procedures for statistical data analysis and better graphic representation. Thus, the objective of this work was to identify the spatial variability of T. limbativentris as a function of irrigated rice phenology in different crops.

\section{MATERIAL AND METHODS}

The study was conducted in the municipality of Santa Maria, Rio Grande do Sul, Brazil (latitude $29^{\circ} 38^{\prime} \mathrm{S}$ and longitude $54^{\circ} 03^{\prime} \mathrm{W}$ ), in an area of 20.12 ha, subdivided into four crops from 0.25 to 14.1 ha, surrounded by shrub, tree and field vegetation. The local climate, according to the Köppen classification, is Cfa type, humid subtropical, with no dry season and hot summers (HELDWEIN et al., 2009). There was no use of insecticides during the execution of the research.

Grids of $30 \times 30 \mathrm{~m}$ were generated in each field, resulting in 143 sample units in Field 1, 385 sample units in Field 2, 13 sample units in Field 3 and 30 sample units in Field 4 (Fig. 1). Each sampling point corresponded to $1 \mathrm{~m}^{2}$ (200 plants). At each sampling point, adults of $T$. limbativentris were counted by direct visual counting.

From the sowing, seven evaluations were carried out during the day: the first evaluation (A1) at stage V3 corresponding to the necklace formed on the $3^{\text {rd }}$ main stem leaf; the second evaluation (A2) at stage V6 corresponding to the necklace formed on the $6^{\text {th }}$ leaf of the main stem; the third evaluation (A3) at stage V9 (R0) corresponding to the initiation of the panicle; the fourth evaluation (A4) at stage V13 (R2) corresponding to the formation of the flag leaf collar (rubber); the fifth assessment (A5) at stage R4 corresponding to the anthesis; the sixth evaluation (A6) at the R6 stage corresponding to the elongation of one or more grains in the shell and the seventh evaluation (A7) at the R9 stage corresponding to the complete maturity of the grains in the panicle (COUNCE et al., 2000).

In each evaluation, the number of adults of $T$. limbativentris per $\mathrm{m}^{2}$ was applied to descriptive and geostatistical analyzes. For data sets with positive asymmetry, the hypothesis of normality of the data was tested by the Shapiro-Wilk test, at $5 \%$ of significance and, when not satisfied, they underwent

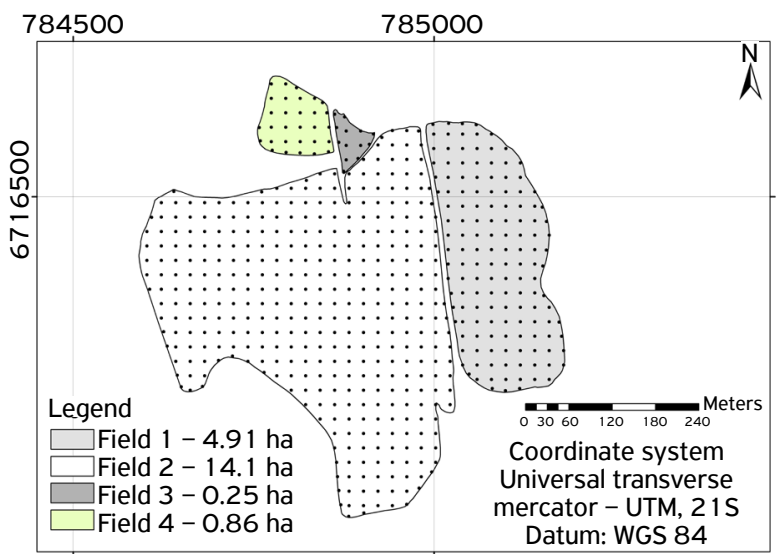

Figure 1. Study area subdivided into four fields (Field 1:4) with the respective sampling points (hatch point) under irrigated rice cultivation, in Santa Maria, Rio Grande do Sul, Brazil. 
the Box-Cox transformation (BOX; COX, 1964). According to YAMAMOTO; LANDIM (2013), there is no need for data transformation for data with normal distribution or with negative asymmetry.

Then, the data on the number of adults of Tibraca limbativentris per $\mathrm{m}^{2}$ were submitted to geostatistical analysis to verify the existence of spatial dependence, by adjusting the theoretical models to the isotropic experimental semivariograms based on the presupposition of stationary intrinsic hypothesis (Eq. 1):

$$
\gamma(h)=\frac{1}{2 N(h)} \sum_{i=1}^{N(h)}\left[Z\left(x_{i}\right)-Z\left(x_{i}+h\right)\right]^{2}
$$

Where $y$ is the semivariance and $\mathrm{N}(\mathrm{h})$ is the number of measured value pairs $Z\left(x_{i}\right)$ and $Z\left(x_{i}+h\right)$ separated by a vector $h$.

From the experimental semivariograms, the circular, spherical, tetraspheric, pentaspheric, exponential, Gaussian, rational quadratic, sine cardinal, K-Bessel, J-Bessel and stable semivariograms were adjusted by the weighted least squares algorithm being defined. model parameters: nugget effect $\left(C_{0}\right)$, threshold $\left(C_{0}+C_{1}\right)$ and range $(a)$ estimated by JOHNSON et al. (2001).

Subsequently, the spatial dependence index (SDI) (Eq. 2) was estimated, which represents a percentage ratio of the spatial dependence, quantified by the semivariogram model, contributes to the variability of the data.

$$
I D E=\frac{C_{1}}{C_{0}+C_{1}}
$$

Being classified as strong (SDI > 75\%), medium $(25<$ SDI $\leq 75 \%)$ and low (SDI $\leq 25 \%)$ (ZIMBACK, 2001; SOUZA et al., 2008). In the presence of spatial dependence between the data, $\mathrm{KO}$ inferences were made, estimating values in unmeasured locations.

From the cross-validation technique between estimated and observed values were selected models semivariogram, based on the weight sum criterion assigned to indicators for the linear regression equation: intersection "a" slope "b" and coefficient of determination " $\mathrm{R}$ ", mean of errors, standard deviation of errors, mean square root of errors and the mean square root of errors standardized, according to WEBSTER; OLIVER (2007) and PASINI et al. (2014).

For the representation of T. limbativentris dispersion in plant developmental stages and crop areas, maps were generated from the estimates obtained from the best semivariogram by assigning estimated values to colors defined by contours at intervals of integers. The projection used was the Universal Transverse Mercator in horizontal Datum WGS 84 and vertical Imbituba, Santa Catarina, Brazil.

\section{RESULTS AND DISCUSSION}

A total of 16,107 adults of T. limbativentris were registered, corresponding to an average of 4.02 adults $\mathrm{m}^{-2} \cdot \mathrm{crop}^{-1}$.evaluation ${ }^{-1}$. The number of individuals per $\mathrm{m}^{2}$ quantified was inversely proportional to the size of the cultivation area, where crops with larger areas had lower population densities; however, due to the greater number of samples, crops with larger areas had a higher population (Table 1). According to AWMACK; LEATHER (2002) the greater the number of opportunities for the species of insect pest in a given area, the greater its population.

The largest number of adults $(10,454)$ was obtained in Field 2, with an average of adults per sample of $3.87 \cdot \mathrm{m}^{-2}$.assessment $\mathrm{t}^{-1}$, only higher than the average value found in Field $1\left(3.34 \cdot \mathrm{m}^{-2}\right.$ assessment $\left.{ }^{-1}\right)$ (Table 1$)$. The smallest number of adults (147) was found in Field 3 with the largest number of adults per sample $\left(11 \cdot \mathrm{m}^{-2}\right.$ evaluation $\left.{ }^{-1}\right)$, followed by Field 4 with 6.19 adults $\mathrm{m}^{-2}$ evaluation ${ }^{-1}$. Among the four sampled crops, those with the smallest areas had the highest average of adults per $\mathrm{m}^{2}$ per evaluation. According to PASINI (2013), the size of the cultivation area and the average number of T. limbativentris are inversely proportional, because this species has a close relationship with the host plants located around the cultivation areas, which, in turn, influence the dispersion of the cultivation. The shorter the distance between the host plants and the rice plants, the greater the propensity for this to be infested by T. limbativentris (FERREIRA et al., 1997).

Between the evaluations, the population density in the crops was increasing from the first to the sixth evaluation and decreasing from the sixth to the seventh (Table 1). According to REISIG et al. (2013), hemipterans have limited dispersion capacity, starting from the borders to the center of the cultivation areas, gradually increasing the population density, due to the high biotic potential of $T$. limbativentris, considering the number of eggs per female above 600 (FERREIRA et al., 1997), and its dispersion as observed in the evaluations carried out. However, when the rice plants reach maturity, they become less attractive to T. limbativentris. The adult insect, when making the test sting, does not find the necessary characteristics of fabrics and food to satisfy its needs, which influences its migration from crops to the surrounding areas (LEE et al., 2014). In these places, they find plants with better characteristics, favoring the reduction of the population of pest insects in the cultivation areas and guaranteeing a new infestation of pest insects in the next harvest.

The concentration of individuals in regions close to the borders, in the first evaluations, inflated the standard deviation values in Fields 1 and 2. This situation generated a high difference between the sampled values taken in the same field and assessment, thus inflating the values of the coefficient of variation (CV). During the evaluations, the standard deviation values increased, but the averages increased in greater 
proportions, which contributed to the reduction of the $\mathrm{CV}$ values in the last evaluations performed (Table 1). In most evaluations $(85.7 \%)$, the asymmetry was positive, influenced by the greater amount of low values or zeros, as in Fields 1 and 2 in the first evaluation (A1). This behavior of the data distribution is linked to the dispersion of T. limbativentris in the crops and its concentration in areas close to the borders of the crops, mainly in larger fields.

Based on geostatistical analysis and cross-validation, the best semivariograms were defined (Table 2). Although in four situations the semivariograms showed effects attributed to random variation (nugget effect) (Table 2, Field 3 in A2 and A7, Field 4 in A1 and A6), the nugget effect was not very representative, not influencing the SDI, for all evaluations considered strong $(\geq 75 \%)$, emphasizing that the spatial distribution of the population of T. limbativentris in crops and assessments showed strong spatial dependence (ZIMBACK, 2001; SOUZA et al., 2008). The range values were estimated between 36.9 and $261.8 \mathrm{~m}$, considering the sampling grid used as appropriate. According to YAMAMOTO; LANDIM (2013), the range value determines the number of values used in the interpolation, the higher the value, the greater the reliability of the estimates. Considering the adjustment of the theoretical semivariogram models and the spatial dependence

Table 1. Descriptive statistics on the number of adults of Tibraca limbativentris (Hemiptera: Pentatomidae) per $\mathrm{m}^{2}$ sampled in seven evaluations in irrigated rice fields. Santa Maria, Rio Grande do Sul, Brazil.

\begin{tabular}{|c|c|c|c|c|c|c|c|c|c|c|c|c|c|c|}
\hline \multirow{2}{*}{ Statistics } & \multicolumn{7}{|c|}{ Evaluation } & \multicolumn{7}{|c|}{ Evaluation } \\
\hline & A1 & $\mathrm{A} 2$ & A3 & A4 & A5 & A6 & A7 & A1 & A2 & A3 & A4 & A5 & A6 & A7 \\
\hline & \multicolumn{7}{|c|}{ Field 1} & \multicolumn{7}{|c|}{ Field 2} \\
\hline Samples & 143 & 143 & 143 & 143 & 143 & 143 & 143 & 385 & 385 & 385 & 385 & 385 & 385 & 385 \\
\hline Average & 0.80 & 1.34 & 2.44 & 4.27 & 5.17 & 5.48 & 3.95 & 0.08 & 2.29 & 3.18 & 4.17 & 5.57 & 6.31 & 5.55 \\
\hline Standard deviation & 1.08 & 1.50 & 1.93 & 2.85 & 3.25 & 3.74 & 2.89 & 0.41 & 2.46 & 2.88 & 3.54 & 4.37 & 4.87 & 3.97 \\
\hline Coefficient variation & 1.36 & 1.11 & 0.79 & 0.67 & 0.63 & 0.68 & 0.73 & 5.09 & 1.08 & 0.90 & 0.85 & 0.78 & 0.77 & 0.72 \\
\hline Interval & 5 & 7 & 8 & 12 & 13 & 15 & 10 & 4 & 11 & 12 & 18 & 24 & 26 & 23 \\
\hline Minimum & 0 & 0 & 0 & 0 & 0 & 0 & 0 & 0 & 0 & 0 & 0 & 0 & 0 & 0 \\
\hline Maximum & 5 & 7 & 8 & 12 & 13 & 15 & 10 & 4 & 11 & 12 & 18 & 24 & 26 & 23 \\
\hline Sum & 114 & 192 & 349 & 610 & 739 & 783 & 565 & 31 & 881 & 1224 & 1606 & 2146 & 2429 & 2137 \\
\hline Total Field & \multicolumn{7}{|c|}{3.352} & \multicolumn{7}{|c|}{10.454} \\
\hline Assimetry & 1.35 & 1.32 & 0.64 & 0.43 & 0.44 & 0.87 & 0.40 & 6.74 & 1.13 & 0.73 & 0.80 & 0.83 & 0.92 & 1.06 \\
\hline Kurtosis & 1.35 & 1.90 & -0.04 & -0.34 & -0.47 & -0.27 & -1.21 & 52.79 & 0.44 & -0.52 & 0.14 & 0.89 & 0.88 & 1.77 \\
\hline$p$-value SW test & 0.01 & 0.00 & 0.00 & 0.00 & 0.00 & 0.00 & 0.01 & 0.00 & 0.00 & 0.00 & 0.00 & 0.00 & 0.01 & 0.00 \\
\hline$\lambda$ (Box-Cox) & -0.68 & 0 & 0.43 & 0.58 & 0.58 & 0.27 & 0.43 & -2.5 & 0 & 0 & 0.33 & 0.43 & 0.43 & 0.43 \\
\hline \multirow[t]{2}{*}{$p$-value SW test } & 0.1 & 0.06 & 0.06 & 0.07 & 0.08 & 0.06 & 0.15 & 0.04 & 0.06 & 0.08 & 0.07 & 0.06 & 0.11 & 0.1 \\
\hline & \multicolumn{7}{|c|}{ Field 3} & \multicolumn{7}{|c|}{ Field 4} \\
\hline Samples & 13 & 13 & 13 & 13 & 13 & 13 & 13 & 30 & 30 & 30 & 30 & 30 & 30 & 30 \\
\hline Average & 2.15 & 4.00 & 6.31 & 16.15 & 18.92 & 17.54 & 11.92 & 0.90 & 1.70 & 3.67 & 8.07 & 10.47 & 12.30 & 6.23 \\
\hline Standard deviation & 0.899 & 1.633 & 1.75 & 3.363 & 4.499 & 2.402 & 1.498 & 0.803 & 1.317 & 1.845 & 4.042 & 4.876 & 3.771 & 1.5687 \\
\hline Coefficient variation & 0.42 & 0.41 & 0.28 & 0.21 & 0.24 & 0.14 & 0.13 & 0.89 & 0.77 & 0.50 & 0.50 & 0.47 & 0.31 & 0.25 \\
\hline Interval & 2 & 4 & 5 & 9 & 13 & 9 & 6 & 3 & 4 & 6 & 15 & 16 & 15 & 6 \\
\hline Minimum & 1 & 2 & 4 & 12 & 13 & 14 & 9 & 0 & 0 & 0 & 3 & 5 & 6 & 4 \\
\hline Maximum & 3 & 6 & 9 & 21 & 26 & 23 & 15 & 3 & 4 & 6 & 18 & 21 & 21 & 10 \\
\hline Sum & 28 & 52 & 82 & 210 & 246 & 228 & 155 & 27 & 51 & 110 & 242 & 314 & 369 & 187 \\
\hline Total Field & \multicolumn{7}{|c|}{1.001} & \multicolumn{7}{|c|}{1.300} \\
\hline Assimetry & -0.34 & -0.14 & 0.32 & 0.01 & 0.31 & 0.78 & -0.02 & 0.62 & 0.41 & -0.50 & 1.03 & 0.90 & 0.34 & 0.68 \\
\hline Kurtosis & -1.78 & -1.68 & -1.18 & -1.67 & -1.48 & 0.86 & 1.05 & 0.06 & -0.86 & -0.93 & 0.48 & -0.25 & -0.63 & -0.17 \\
\hline$p$-value SW test & 0.06 & 0.07 & 0.26 & 0.19 & 0.25 & 0.29 & 0.19 & 0.02 & 0.01 & 0.02 & 0.01 & 0.01 & 0.19 & 0.02 \\
\hline$\lambda$ (Box-Cox) & - & - & - & - & - & - & - & 0.32 & 0.47 & - & 0 & -0.43 & - & -0.48 \\
\hline$p$-value SW test & - & - & - & - & - & - & - & 0.07 & 0.12 & - & 0.41 & 0.29 & - & 0.22 \\
\hline
\end{tabular}


Table 2. Nugget effect (CO), structural variable (C1), range (a), gamma function $(\Gamma)$ and spatial dependence index (SDI) of the theoretical models of semivariogram selected in different assessments and crops. Santa Maria, Rio Grande do Sul.

\begin{tabular}{|c|c|c|c|c|c|c|}
\hline \multirow{2}{*}{ Evaluation } & \multirow{2}{*}{ Model } & \multicolumn{5}{|c|}{ Estimates } \\
\hline & & $c_{0}$ & $C_{1}$ & a & ґ & SDI \\
\hline \multicolumn{7}{|c|}{ Field 1} \\
\hline A 1 & Pentaspheric & 0.000 & 1.574 & 252.9 & & 100 \\
\hline A2 & Circular & 0.000 & 3.830 & 256.5 & & 100 \\
\hline A3 & Tetraspheric & 0.000 & 1.132 & 38.3 & & 100 \\
\hline A4 & Circular & 0.000 & 1.912 & 261.8 & & 100 \\
\hline A5 & Gaussian & 0.000 & 4.378 & 43.4 & & 100 \\
\hline A6 & K-Bessel & 0.000 & 4.649 & 36.9 & 10.0 & 100 \\
\hline A7 & Gaussian & 0.000 & 3.063 & 41.4 & & 100 \\
\hline \multicolumn{7}{|c|}{ Field 2} \\
\hline $\mathrm{A} 1$ & Circular & 0.000 & 0.962 & 153.9 & & 100 \\
\hline A2 & Tetraspheric & 0.000 & 8.762 & 478.4 & & 100 \\
\hline A3 & Pentaspheric & 0.000 & 16.514 & 487.3 & & 100 \\
\hline A4 & K-Bessel & 0.000 & 3.762 & 42.2 & 9.1 & 100 \\
\hline A5 & Circular & 0.000 & 4.259 & 39.5 & & 100 \\
\hline A6 & K-Bessel & 0.045 & 6.972 & 124.1 & 7.8 & 99 \\
\hline A7 & Stable & 0.000 & 5.999 & 40.3 & 2.0 & 100 \\
\hline \multicolumn{7}{|c|}{ Field 3} \\
\hline $\mathrm{A} 1$ & J-Bessel & 0.000 & 7.746 & 71.7 & 10.0 & 100 \\
\hline A2 & Circular & 0.284 & 13.820 & 98.0 & & 98 \\
\hline A3 & Circular & 0.000 & 10.047 & 51.2 & & 100 \\
\hline A4 & Circular & 0.000 & 34.963 & 70.6 & & 100 \\
\hline A5 & Circular & 0.000 & 48.328 & 56.1 & & 100 \\
\hline A6 & J-Bessel & 0.000 & 13.511 & 41.9 & 3.9 & 100 \\
\hline A7 & Cardinal Sine & 0.340 & 5.165 & 84.1 & & 94 \\
\hline \multicolumn{7}{|c|}{ Field 4} \\
\hline $\mathrm{A} 1$ & Cardinal Sine & 0.035 & 1.855 & 90.0 & & 98 \\
\hline A2 & K-Bessel & 0.000 & 3.466 & 47.4 & 10.0 & 100 \\
\hline A3 & K-Bessel & 0.000 & 5.204 & 41.7 & 10.0 & 100 \\
\hline A4 & Spheric & 0.000 & 25.562 & 96.7 & & 100 \\
\hline A5 & K-Bessel & 0.000 & 43.606 & 86.9 & 10.0 & 100 \\
\hline A6 & Cardinal Sine & 0.391 & 24.286 & 107.3 & & 98 \\
\hline A7 & Circular & 0.000 & 6.894 & 89.4 & & 100 \\
\hline
\end{tabular}

(Table 2), the spatial distribution maps of T. limbativentris were generated for the crops and development stages of the rice plants (Figs. 2 to 5 ).

For all evaluations, the T. limbativentris dispersion started from the borders towards the center of the cultivation areas, from the surrounding field vegetation. In Field 1, there was a gradual evolution in the area infested by adults of T. limbativentris (Fig. 2), with greater population and dispersion in the A6 assessment. The largest populations were distributed to the south, east and north in all evaluations and coincide with the zones of onset of infestation, with density estimates of up to 16 individuals per $\mathrm{m}^{2}$. In Field 2 (Fig. 3), the infestation by $T$. limbativentris was different from Field 1, occurring on the south and west sides until A3 evaluation. From the fourth assessment, in the border regions on the south, west and north sides, there were areas with low population, as on the east side, influenced by limitations in the dispersion of the insect pest and the region being bordered by Field 1, this area, 


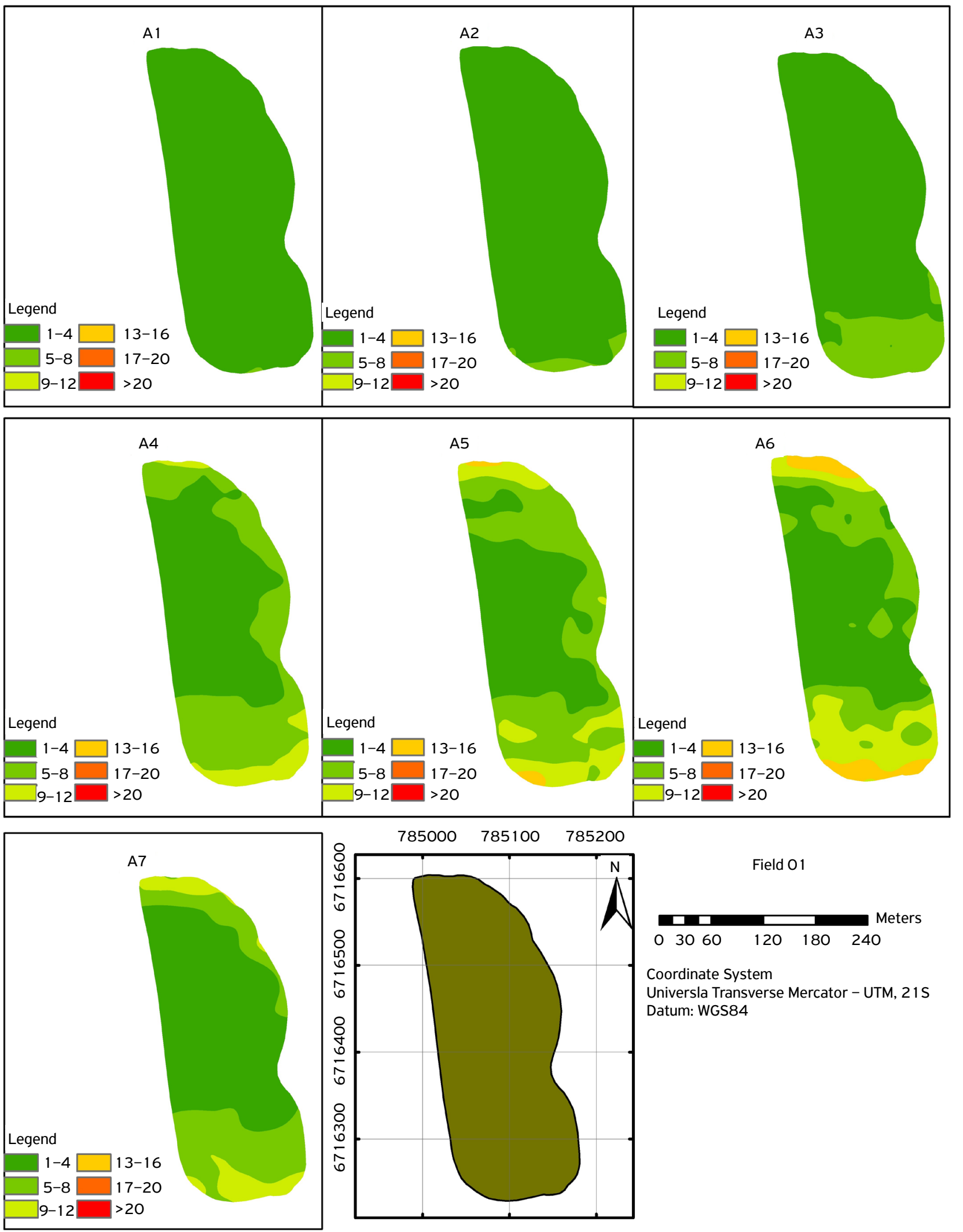

Figure 2. Maps of spatial distribution of adults of Tibraca limbativentris (Hemiptera: Pentatomidae) per $\mathrm{m}^{2}$ interpolated by ordinary kriging for evaluations in Field 1. Santa Maria, Rio Grande do Sul, Brazil. 

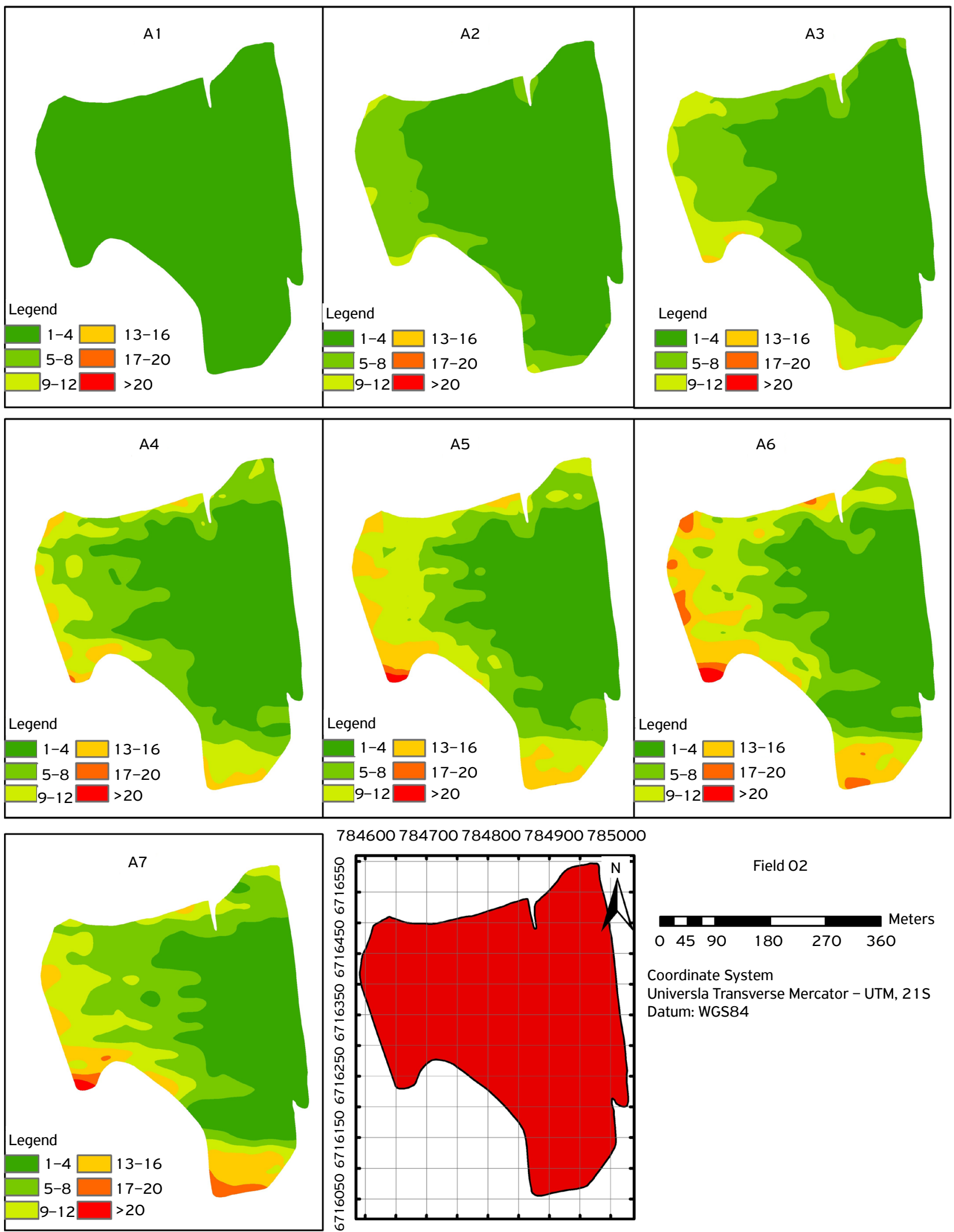

784600784700784800784900785000



Field $\mathrm{O} 2$

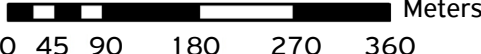

Coordinate System

Universla Transverse Mercator - UTM, $21 \mathrm{~S}$

Datum: WGS84

Figure 3. Maps of spatial distribution of adults of Tibraca limbativentris (Hemiptera: Pentatomidae) per $\mathrm{m}^{2}$ interpolated by ordinary kriging for evaluations in Field 2. Santa Maria, Rio Grande do Sul, Brazil. 

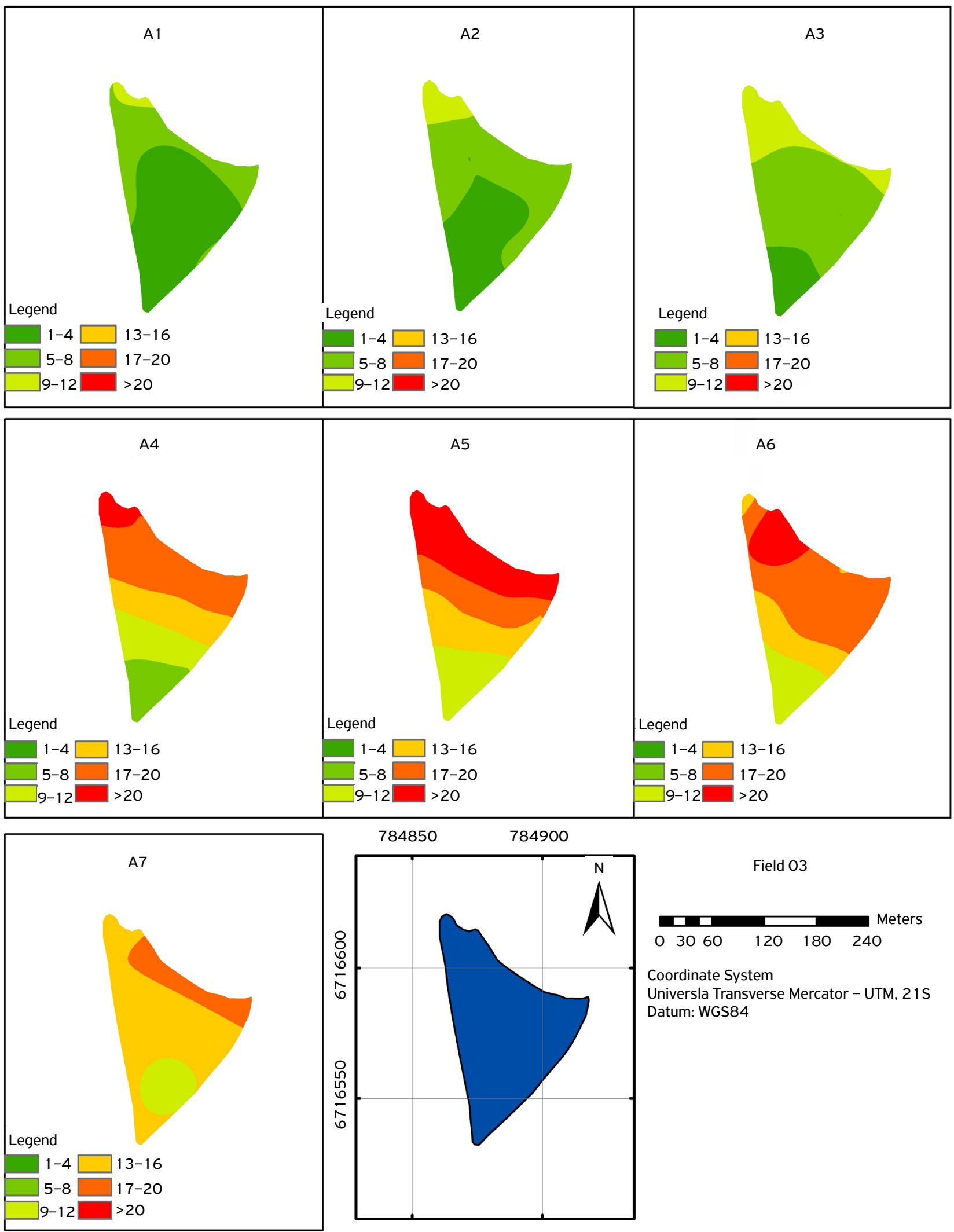

Figure 4. Maps of spatial distribution of adults of Tibraca limbativentris (Hemiptera: Pentatomidae) per $\mathrm{m}^{2}$ interpolated by ordinary kriging for evaluations in Field 3. Santa Maria, Rio Grande do Sul, Brazil. 

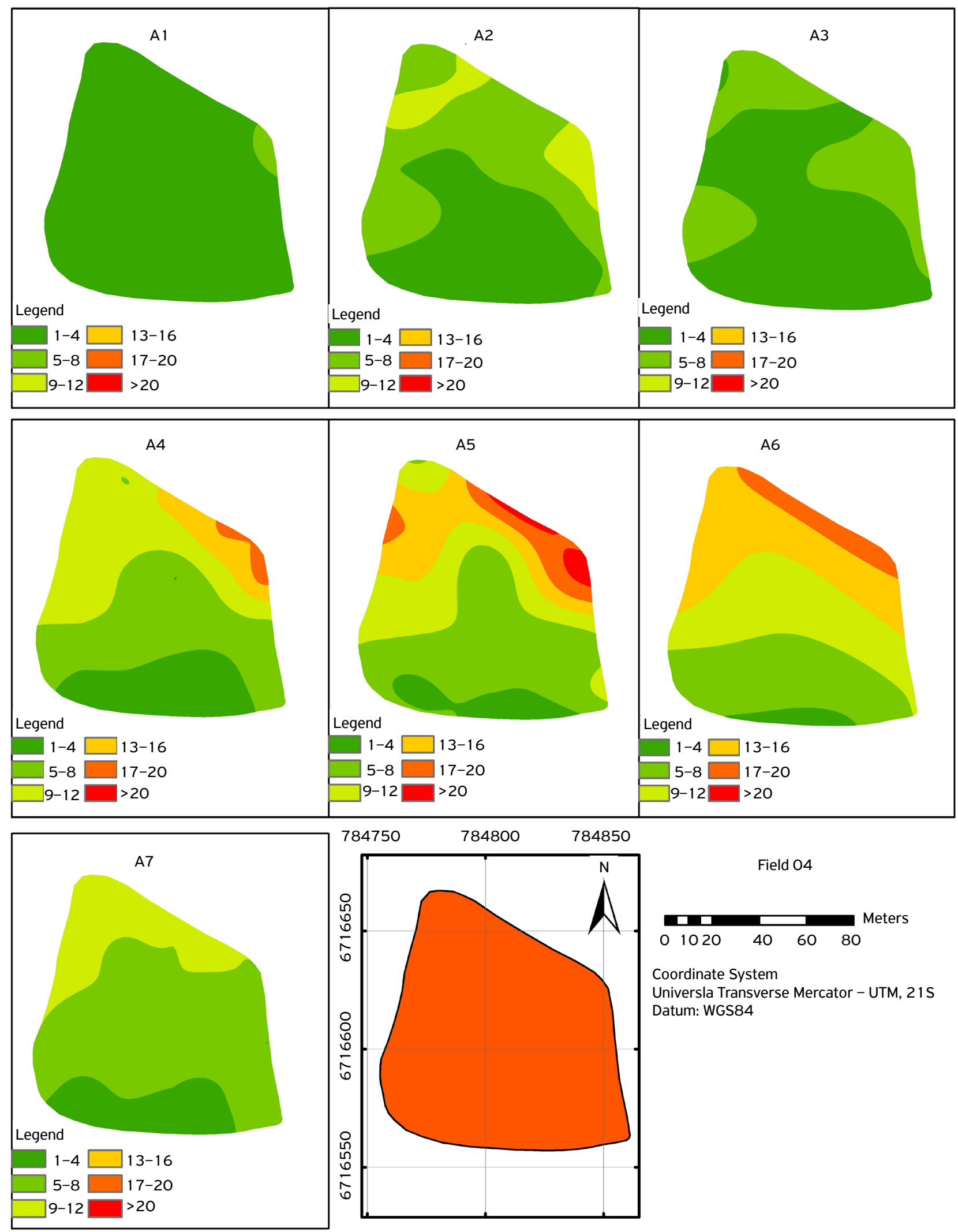

Figure 5. Maps of spatial distribution of adults of Tibraca limbativentris (Hemiptera: Pentatomidae) per $\mathrm{m}^{2}$ interpolated by ordinary kriging for evaluations in Field 4. Santa Maria, Rio Grande do Sul, Brazil. 
without contact with host plant population for the insect pest. In Field 2, the populations reached 26 individuals per $\mathrm{m}^{2}$ in the sixth evaluation, however, the greatest dispersion of insects in the cultivation area was recorded in A7.

In Fields 3 and 4, the infestation was different from that presented in Fields 1 and 2. There was infestation in higher concentrations of the population facing the north in Fields 3 and 4 and a better dispersion of individuals by the cultivation area (Figs. 4 and 5). This behavior was a reflection of the smaller size of the cultivation area in Fields 3 and 4, favoring a wider dispersion in the area cultivated by those of pest insects, where the limited dispersion capacity of hemipterans was not a major factor (REISIG et al., 2013).

Relating the sizes of the cultivation areas, with the dispersion levels associated with the population densities, represented by Figs. 2 to 5, it is possible to verify that the dispersion and the size of the cultivation area are inversely proportional. Suppressive measures of the population density of this insect pest, when adopted, may take into account the size of the cultivation area, where fields with small areas (Fields 3 and 4) should be managed in total area and fields with greater area, due to the limited dispersion capacity of hemipterans (REISIG et al., 2013), can be managed in specific areas, especially when associated with borders with the presence of host plants, limited to ranges of up to $90 \mathrm{~m}$. In practice, in large crops, the localized application may reflect an important reduction in the cost of the crop, and a consequent increase in net profit.

\section{CONCLUSIONS}

The highest population densities were estimated in the anthesis and elongation phase of one or more grains in the husk. Tibraca limbativentris presents dispersion of the borders towards the center of the irrigated rice cultivation area.

ACKNOWLEDGEMENTS: The authors would like to thank Dr. Dionísio Link (in memoriam) for idealizing this project.

FUNDING: To Conselho Nacional de Desenvolvimento Científico e Tecnológico (CNPq, process numbers 305057/20138 and 300663/2013-7), the awards for excellence in research.

CONFLICTS OF INTEREST: All authors declare that they have no conflict of interest.

ETHICAL APPROVAL: Not applicable.

AVAILABILITY OF DATA AND MATERIAL: The datasets generated and/or analyzed during the current study are available from the corresponding author on reasonable request.

AUTHORS' CONTRIBUTIONS: Conceptualization: Pasini, M.P.B.; Engel, E.; Lúcio A.D.C. Data curation: Pasini, M.P.B. Formal analysis: Pasini, M.P.B.; Engel, E.; Lúcio A.D.C.; Cargnelutti Filho, A. Methodology: Pasini, M.P.B.; Engel, E.; Lúcio A.D.C Cargnelutti Filho, A. Writing - review \& editing: Pasini, M.P.B.; Engel, E.; Lúcio A.D.C; Cargnelutti Filho, A.; Ribeiro, A.L.P.; Zamberlan, J.F.; Bortolotto, R.P.

| || | | | | | | | | | | | | | | | | | | | | | | | | | | | | | | | | | | | | | | | | | | | | | | | | | | | | | | | | | | | | | | | | | | | | | | | | | | | | | | | | | | | | | | | | | | | | | | | | | | | | | | | | | | | | | | | | | | | | | | | | | | | | | | | | | | | | | | | | | | | | | | | | | | | | | | | | | | | | | | | | | | | | | | | | | | | | | | | | | | | | | | | | | | | | | | | | | | | | | | | | | | | |

\section{REFERENCES}

AWMACK, C.S.; LEATHER, S.R. Host plant quality and fecundity in herbivorous insects. Annual Review Entomology, Palo Alto, v.47, p.817-844, 2002. https://doi.org/10.1146/annurev. ento.47.091201.145300

BOX, G.E.P.; COX, D.R. An analysis of transformations. Journal of the Royal Statistical Society: Series B (Methodological), Malden, v.26, n.2, p.211-243, 1964. https://doi.org/10.1111/j.2517-6161.1964. tb00553.x

COELHO, E.C.; SOUZA, E.G.; URIBE-OPAZO, M.A.; PINHEIRO NETO, R. Influência da densidade amostral e do tipo de interpolador na elaboração de mapas temáticos. Acta Scientiarum. Agronomy, Maringá, v.31,n.1, p.165-174, 2009. https://doi.org/10.4025/ actasciagron.v31i1.6645
COUNCE, P.A.; KEISLING, T.C.; MITCHEL, A.J. A uniform, objective, and adaptive system for expressing rice development. Crop Science, Texas, v.40, n.2, p.436-443, 2000. https://doi.org/10.2135/ cropsci2000.402436x

DINARDO-MIRANDA, L.L.; FRACASSO, J.V.; PERECIN, D. Variabilidade espacial de populações de Diatraea saccharalis em canaviais e sugestão de método de amostragem. Bragantia, Campinas, v.70, n.3, p.577-585, 201 1. https://doi.org/10.1590/ S0006-87052011005000008

FERREIRA, E.; ZIMMERMANN, F.J.D.; SANTOS, A.B.; NEVES, B.P. O percevejo-do-colmo na cultura do arroz. Documentos 75. Goiânia: EMBRAPA-CNPAF, 1997. 43p. 
HELDWEIN, A.B.; BURIOL, A.G; STRECK, N.A. O clima de Santa Maria. Ciência @ Ambiente, Santa Maria, v.38, n. 1, p.43-58, 2009.

JOHNSON, K.; VER HOEF, J.M.; KRIVORUCHKO, K; LUCAS, N. Using ArcGIS geostatistical analyst. Redlands: ESRI, 2001. 306p. Available from: https://dusk.geo.orst.edu/gis/geostat_analyst. pdf. Access on: 22 Jun. 2017.

LEE, D.-H.; NIELSEN, A.L.; LESKEY, T.C. Dispersal capacity and behavior of nymphal stages of Halyomorpha halys (Hemiptera: Pentatomidae) evaluated under laboratory and field conditions. Journal of Insect Behavior, Hatfield, v.27, n.5, p.639-651, 2014. https://doi.org/10.1007/s10905-014-9456-2

OLIVEIRA, J.V.; FREITAS, T.F.S.; FIUZA, L.M.; MENEZES, V.G. DOTTO, G. Manejo de insetos associados à cultura do arroz irrigado. Cachoeirinha: IRGA, 2010. 54p.

PASINI, M.P.B. Monitoramento da população de percevejos pentatomídeos no arroz irrigado com a aplicação do sistema de informação geográfica. 2013. Undergraduate thesis -Universidade Federal de Santa Maria, Santa Maria, 2013. Available from: https://repositorio.ufsm.br/bitstream/handle/1/184/Pasini Mauricio_Paulo_Batistella.pdf?sequence $=1$ \&isAllowed $=y$. Access on: 15 Dec. 2016

PASINI, M.B.P.; LÚCIO, A.D.; CARGNELUTI, A.F. Semivariogram models for estimating fig fly population density throughout the year. Pesquisa Agropecuária Brasileira, Brasília, v.49, n.7, p.493-505, 2014 . https://doi.org/10.1590/ so $100-204 \times 2014000700001$

PASINI, M.P.B.; LÚCIO, A.D.; FRONZA, D.; WEBER, L.S. Krigagem ordinária e inverso da distância ponderada aplicados na espacialização da população da mosca-do-figo. Agrária-Revista Brasileira de Ciências Agrárias, Recife, v.10, n.3, p.452-459, 2015. https://doi.org/10.5039/agraria.v10i3a3789

PAZINI, J.B.; BOTTA, R.A.; SILVA, F.F. Mortalidade de percevejo-do-colmo do arroz no preparo do solo para cultivo mínimo. Pesquisa Agropecuária Brasileira, Brasília, v.47, n.7, p.1022-1024, 2012. https://doi.org/10.1590/ so $100-204 \times 2012000700020$

PAZINI, J.B.; BOTTA, R.A.; SEIDEL, E.J.; SILVA, F.F.; MARTINS, J.F.S.; BARRIGOSSI, J.A.F.; RÜBENICH, R. Geostatistics applied to the study of the spatial distribution of Tibraca limbativentris in flooded rice fields. Ciência Rural, Santa Maria, v.45, n.6, p.1006-1012, 2015. https://doi. org/10.1590/0103-8478cr20140841
RAMPELOTTI, F.T.; FERREIRA, A.; TCACENCO, F.A.; MARTINS, J.F.S.; GRÜTZMACHER, A.D.; PRANDO, H.F. Diversidade genética de Tibraca limbativentris Stål (Hemiptera: Pentatomidae) de Santa Catarina e do Rio Grande do Sul, usando marcadores RAPD. Neotropical Entomology, Londrina, v.37, n.1, p.20-29, 2008. https://doi.org/10.1590/S1519-566X2008000100004

REISIG, D.D.; ROE, M.; DHAMMI, A. Dispersal pattern and dispersion of adult and nymph stink bugs (Hemiptera: Pentatomidae) in wheat and corn. Environmental Entomology, Hamden, v.42, n.6, p.1184-1192, 2013. https://doi.org/10.1603/EN13166

SILVA, A.F.; LIMA, J.S.S.; OLIVEIRA, R.B. Métodos de interpolação para estimar o pH em solo sob dois manejos de café arábica. Idesia, Arica, v.28, n.2, p.61-66, 2010. https://doi.org/10.4067/ S0718-34292010000200007

SOUZA, G.S.; LIMA, J.S.S; SILVA, S.A.; OLIVEIRA, R.B. Variabilidade espacial de atributos químicos em um Argissolo sob pastagem. Acta Scientiarum. Agronomy, Maringá, v.30, n.4, p.589-596, 2008. https://doi.org/10.4025/actasciagron.v30i4.5322

SOUZA, J.R.; FERREIRA, E.; CARGNELUTTI FILHO, A.; BOIÇA JUNIOR, A.L.; CHAGAS, E.F.; MONDEGO, J.M. Divergência genética de cultivares de arroz quanto à resistência a Tibraca limbativentris Stål (Hemiptera: Pentatomidae). Neotropical Entomology, Londrina, v.38, n.5, p.671-676, 2009. https://doi. org/10.1590/S1519-566X2009000500018

SOUZA, G.S.; LIMA, J.S.S.; XAVIER, A.C.; ROCHA, W.S.D. Krigagem ordinária e inverso do quadrado da distância aplicados na espacialização de atributos químicos de um argissolo. Scientia Agraria, Curitiba, v. 11 , n. 1, p.73-81, 2010. https://doi.org/10.5380/rsa.v1 1i1.15939

WALZER, A.; MODER, K.; SCHAUSBERGER, P. Spatiotemporal within-plant distribution of the spider mite Tetranychus urticae and associated specialist and generalist predators. Bulletin of Entomological Research, Cambridge, v.99, n.5, p.457-466, 2009. https://doi.org/10.1017/S0007485308006494

WEBSTER, R.; OLIVER, M.A. Geostatistics for environmental scientists, second edition. Chichester: John Wiley \& Sons, 2007. 315p. https://doi.org/10.1002/9780470517277

YAMAMOTO, J.K.; LANDIM, P.M.B. Geoestatística: Conceitos e Aplicações. São Paulo: Oficina de Textos, 2013. 215p.

ZIMBACK, C.R.L. Análise espacial de atributos químicos de solo para o mapeamento da fertilidade do solo. 2001. Thesis - Universidade Estadual Paulista, Botucatu, 2001 